\title{
Religion and CSR: a systematic literature review
}

\author{
Dominik van Aaken ${ }^{1}$. Florian Buchner ${ }^{1}$
}

Published online: 18 March 2020

(c) The Author(s) 2020

\begin{abstract}
Around the turn of the millennium, a growing body of literature emerged that focuses on the relationship between religion and corporate social responsibility (CSR). Although the connection between religion and CSR seems obvious at first, the literature in this field yields conflicting results. This paper provides the first systematic review of the literature that deals with the relation between religion and CSR. We categorized the literature into a matrix, which distinguishes the level of analysis (micro/macro) on the one hand and types of approaches (normative/empirical) on the other. Results are clustered according to the religions they address to identify similarities between and locate trends in research.
\end{abstract}

Keywords Business ethics · Corporate social responsibility $\cdot$ Faith $\cdot$ Religion

JEL Classification M10 $\cdot$ N30 $\cdot$ Z12

\section{Introduction}

In the spirit of Max Weber (2001 [1904]), a vast number of studies have asked whether religion has a significant impact on human behavior (e.g., Singer 1966; Blum and Dudley 2001). Weber dedicated himself to the question of how religions shape modern society, with a particular focus on the relation between religion and power structures, culture, and economics (Weber 1963; Tyrell 1992). Weber concluded that religion strongly shapes society: for example, Christian traditions in Europe led to the emergence of rational science, as well as to capitalism as an economic system.

Regarding the business context, scholars argued that religiosity has a strong impact on values, which, in turn, affect attitudes and ultimately individual behavior at

\footnotetext{
$\bowtie$ Dominik van Aaken

Dominik.vanAaken@sbg.ac.at

Florian Buchner

Florian.Buchner@sbg.ac.at

1 University of Salzburg, Kapitelgasse 5-7, 5020 Salzburg, Austria
} 
work (Parboteeah 2009; Ramasamy, Yeung and Au 2010a,b). Brown, Vetterlein, and Roemer-Mahler (2010), for example, showed that managers' personal values and views on religion not only have strong effects on their own decisions, but also influence their subordinates' attitudes. Researchers have also addressed the relationship between religion and CSR (e.g., Agle and Van Buren 1999; Angelidis and Ibrahim 2004; Giacalone and Jurkiewicz 2004). CSR, understood in a broad way as a firm's responsibility to society (see also Bowen 1953: Frederick 1994), seems to have a clear relation to religion and some scholars even credit the origins of CSR to theological and religious actors and contributions. According to De George (1987), Catholic social encyclicals and the work of Reinhold Niebuhr on the Protestant side constituted the earliest principal activity in this field. In this vein, religion should be seen as an integral part of the evolution of CSR as a concept, for both religion and CSR deal with human meaning, destiny, purpose, and morality (Frederick 1998).

However, despite the obvious connection, the literature yields conflicting results about the role of religion and CSR (Weaver and Agle 2002). While several authors have already taken on the task of mapping the CSR literature, unveiling its underlying theories and assumptions (Carroll 1999; Garriga and Melé 2004; Secchi 2007), the relation between CSR and religion has not been addressed to date. The aim of this paper is to fill this gap by performing a systematic review of the literature that deals with religion and CSR. In this way, we contribute to the literature by identifying what we already know and what still remains to be investigated.

In the next section we start this process by developing a conceptual framework that enables us to analyse the literature in a systematic fashion. Afterwards we outline our methodology. We then present our results focusing on the four fields of our conceptual framework, followed by an discussion and conclusion.

\subsection{Conceptual framework for analyzing the literature on religion and CSR}

Reviews of the CSR literature often focus on specific disciplines such as marketing (Enderle and Murphy 2009; Maignan and Ferrell 2004), psychology (Aguinis 2011), or information systems (Elliot 2011). While informative, a broader overview improves our understanding across different disciplines-beyond extant fragmented approaches. In what follows, we develop a conceptual framework that enables us to systematize the literature across different disciplines. Generally, a conceptual framework consists of relevant characteristics identified from previous research that provides an internal structure, which in turn offers a starting point for analysis (Morse et al. 2002). In our conceptual framework, we use distinctions that are common in the field. First, we follow Aguinis and Glavas's (2012) approach of distinguishing studies at the macro level from those at the micro level. The macro level addresses CSR research at the institutional level, which includes laws, regulatory standards, cultural-cognitive, and normative constructs (Scott 1995), as well as at the organizational level, which focuses on the firm level. Research on this level investigates, for example, how religion can mitigate specific CSR practices of a firm (Du, Jian, Lai, Du and Pei $2015 \mathrm{a}, \mathrm{b})$. The micro level deals with research at the individual level, that is, in relation to the individuality of a person or persons. Research on this level addresses, 
for example, the relationship between executives' intrinsic religiosity (that treats religion as an end in itself), extrinsic religiosity (that treats religion as an instrumental means to suit oneself), and executives' attitudes towards the various layers of CSR (Mazereeuw-van der Duijn Schouten et al. 2014).

We also apply the findings of Swanson (1999), Lockett, Moon and Visser (2006), and Küpper (1974, 2011a), and categorize the literature about CSR and religion by distinguishing between research that takes normative and empirical approaches. Research within a normative approach is centred on moral evaluation, judgement, and prescription of human action (Küpper 2011c). Within this normative evaluation, there is always an element of recommendation or a specific "ought." In contrast to normative approaches, empirical approaches explain, measure, and predict observable causal relationships between variables (Küpper 2011b; Treviño and Weaver 1994). Although the role of empirical research in CSR has been controversial, it holds a special importance for the practical application of normative CSR theories (Schreck, van Aaken and Donaldson 2013).

Our framework contains both micro and macro levels of analysis, as well as normative and empirical types of approaches. This results in a matrix where one axis relates to the level of analysis (subdivided into micro and macro research) and one axis deals with types of approaches (subdivided into normative and empirical research). Hence, we have four categories: macro-normative, macro-empirical, micro-normative, and micro-empirical.

\subsection{Methodology}

Our literature review follows a Prisma-Flow Diagram (Moher, Liberati, Tetzlaff, Altman and the Prisma Group 2009). Records are found through a database search, and then screened and assessed for eligibility by the researchers. Underlying this process is a Boolean database query, which is carried out using the operators "AND", "OR", and "NOT". The search terms used were deliberately rather general (for the full specification of the search terms, see Fig. 1). The search terms for CSR were mainly derived from Carroll (1991, 1999) and Garriga and Melé (2004). We also used wildcard characters: the search term "Corporate Social," for example, covers corporate social responsibility, corporate social responsiveness, and so on. The search terms associated with religion cover the basic terms "religion," "spirituality," and "faith," as well as the names of the world religions. The Boolean search was applied to abstract, title, and keyword.

In order to capture the academic discourse in the field of religion and CSR, we use $\mathrm{A}+, \mathrm{A}$, and B ranked journals listed in the VHB-JOURQUAL 3 ranking, as well as 4*, 4, and 3 ranked journals listed in the 2018 Chartered Association of Business Schools (CABS) academic journal guide. We looked at all scholarly and peer-reviewed journals in English language featured therein. The database utilized was EBSCO Business Source Ultimate, which grants access to most of journals. Journals that were not provided by EBSCO Business Source Ultimate, were collected by hand. The time period reviewed spans 1987-2018. This search yielded 152 academic articles. After carefully screening, 79 articles that specifically deal with the relation between 


\section{( 'Corporate Social' OR CS* OR ‘Corporate Citizenship' OR ‘Corporate Philanthropy' OR 'Social Responsibility' ) \\ AND \\ ( Relig* OR Spirit* OR Faith* OR Islam* OR Muslim* OR Buddh* OR Christian* OR Cathol* OR Protestant* OR Jew* OR Hebrew* OR Hindu*) \\ AND \\ ISSN (all ISSN for A+, A, B Journals in VHB-Jourqual 3 AND 3, 4, 4* Journals in CABS)}

Fig. 1 Search terms

religion and CSR were deemed eligible (for a full list of articles see Appendix A). 83 articles were excluded because they did not address the topic. The high exclusion rate is due to the broad nature of our search terms as, for example, the term "spirit" also captured research dealing with the "spirit of something/someone," a phrase often found in abstracts.

\section{Results}

Every article was assigned to one field within our $2 \times 2$ matrix. The results are distributed rather evenly, except for the micro-normative field, which consists only of three entries only. The field of the macro-empirical research constitutes the largest field with 28 entries, followed by macro-normative with 26 and micro-empirical with 22 articles. The tables in the following section list, first, the author or authors of the article. Second, each article was assigned a specific religion (column 'Religion'), depending on the religion, denomination or concept of religion followed. In this vein, we distinguish between religions such as Christianity or Islam and rather unspecific forms of religion, like spirituality or religiosity. Third, the year of publication is reported, followed by the kind of scientific field in which the article was published (column "Field of Publication"). In the seven fields chosen ("Accounting," "Economics," "Ethics," "Finance," "Management," "Marketing," and "Sector Studies"1), ethics journals are strongly prevalent (e.g., Journal of Business Ethics and Business Ethics Quarterly). Finally, we assigned each article a domain of CSR to which it relates (column "CSR Dimension"). According to Schwartz and Carroll's (2003) "three domain approach", CSR conceptually concerns itself with either economic, legal, or ethical social responsibility. The economic domain captures activities that are intended to have either a direct or an indirect positive economic impact. The legal category of CSR pertains to the responsiveness to legal expectations mandated and expected by society and the state. The ethical domain refers to the ethical responsibilities of business as expected by the general population and relevant stakeholders. These domains can also overlap, which gives us seven variations of CSR: Purely Ethical, Purely Legal, Purely Economic,

\footnotetext{
1 We refer to Sector Studies as research in a specific economic or industrial sector, such as tourism or automotive.
} 
Economic/Ethical, Legal/Ethical, Economic/Legal, and Economic/Legal/Ethical. The sections regarding the results are organized by religion in the order: Christianity, Islam, Judaism, Hinduism, Buddhism, Spirituality/other Religion.

\subsection{Macro-normative}

With 26 entries, the macro-normative category represents one of the largest groups of articles in the reviewed literature (see Table 1). These articles have in common that they follow a normative approach at an institutional level of analysis. The research attributed to this category evaluates various religious normative systems and applies them to the business context. There is a strong prevalence of Catholic Social Teaching (CST) and Islam. CST is based on papal social encyclicals, which are irregularly published and reflect the Catholic church's view on social issues (Frambach and Eissrich 2016). These articles focus particularly on the ethical CSR domain, probably due to the fact that papal encyclicals are treated as a source of moral guidance and focus on the common good rather than on firms' responsibility to make profit. Most CST articles address the employer-employee relationship and the social responsibility of the firm regarding their workers, working conditions, and the concept of work itself. Specifically, they develop ethical principles that can be applied to questions of workplace ethics (Naughton and Laczniak 1993), work-family conflict policies (Guitián 1988), human resource policies (Zigarelli 1993), or to the management's obligation to provide workers with meaningful work, though not at any cost (Tablan 2015). Other CST-related articles focus on implications for socially responsible business conduct, such as transparency in business (Vaccaro and Sision 2011), marketing (Klein and Laczniak 2013), and following the principle of the common good (Goodpaster 2011). Other Christian denominations not affiliated with CST are scarce and mostly used in historical context, when they are referred to as a point of origin for business ethics (De George 1987).

Islam also features predominantly within the sample. Among the researched topics are environmental responsibility and environmental accounting (Kamlaa, Gallhofer and Haslam 2006), corporate governance (Murphy and Smolarski 2018), as well as CSR implications derived from the Hizmet movement (Dreher 2015; Robinson 2015). Judaism and Buddhism are both represented only twice. Judaism is represented through the works of Moses Pava (1996, 1998). Pava applies the concept of "beyond the letter of the law," an ancient Jewish and Talmudic tradition, to the business ethics context in an attempt to bring together classical Friedmanian and pro-social CSR perspectives through the focus of law-abiding practices. Buddhism in this context occurrs only in the context of developing countries. Abeysuriya, Mitchell and White (2007) suggest a moral code based on Buddhist values to guide firms in solving sanitation questions via CSR. Widger (2016) identifies four indigenous forms of CSR in Sri Lanka that promote Buddhism as the nation's dominant religion.

There are also articles that use an unspecific notion of religion and focus on the ethical component of CSR. The relevance of religious partners in building global socially responsible businesses (Wilburn 2009) and the necessity for naturalist theology in the development of new CSR concepts (Fort 1999; Frederick 1998) are examples of this cluster. 
Table 1 Macro-normative research

\begin{tabular}{lllll}
\hline Author & Religion & Year & Field of publication & CSR dimension \\
\hline $\begin{array}{l}\text { Abeysuriya, Mitchell \& } \\
\text { White }\end{array}$ & Buddhist & 2007 & Economics & Ethical \\
Widger & Buddhist & 2016 & Social science & Economic/Ethical \\
De George & Christian & 1987 & Ethics & Ethical \\
Aßländer & CST & 2011 & Ethics & Economic/Ethical \\
Costa \& Ramus & CST & 2012 & Ethics & Economic/Ethical \\
Cremers & CST & 2017 & Ethics & Economic/Ethical \\
Goodpaster & CST & 2011 & Ethics & Ethical \\
Goodpaster, Dean, & CST & 2018 & Ethics & Ethical \\
$\quad$ Naughton \& Shapiro & & & & \\
Guitián & CST & 1988 & Ethics & Economic/Ethical \\
Klein \& Laczniak & CST & 2013 & Ethics & Economic/Ethical \\
Naughton \& Laczniak & CST & 1993 & Ethics & Economic/Ethical \\
Ryan & CST & 2018 & Ethics & Ethical \\
Sison, Ferrero \& Guitiá & CST & 2016 & Ethics & Ethical \\
Tablan & CST & 2015 & Ethics & Economic/Ethical \\
Vaccaro \& Sison & CST & 2011 & Ethics & Ethical \\
Zigarelli & CST & 1993 & Ethics & Ethical \\
Dreher & Islam & 2015 & Ethics & Economic/Legal/Ethical \\
Kamlaa, Gallhofer \& & Islam & 2006 & Accounting & Economic/Legal/Ethical \\
$\quad$ Haslam & & & & \\
Murphy \& Smolarski & Islam & 2018 & Ethics & Ethical \\
Robinson & Islam & 2015 & Ethics & Ethical \\
Pava & Jewish & 1996 & Ethics & Economic/Legal/Ethical \\
Pava & Jewish & 1998 & Ethics & Legal/Ethical \\
Fort & Religion (other) & 1999 & Ethics & Ethical \\
Schaefer & Religion (other) & 2008 & Ethics & Ethical \\
Wilburn & Religion (other) & 2009 & Ethics & Economic/Legal/Ethical \\
Frederick & 1998 & Ethics & Economic/Ethical \\
\hline & & &
\end{tabular}

In sum, Catholicism and Islam dominate the category of macro-normative research on the relation between CSR and religion. We suggest that the reason may lie in the fact that both religions present ready-to-use normative frameworks with strong legitimacy, which can more or less readily be applied to the business context. CST in particular offers a rich source to draw on, because it already addresses social issues and socially responsible business conduct (Calkins 2000). Being mostly published on occasion of a specific social issue, social encyclicals also have the advantage of addressing acute and current topics. Islam presents a similar case. Islam is a "complete" religion, meaning that it strongly influences every aspect of daily life and the morals of its adherents (Khan 2011). It sets extensive normative guidelines for business conduct, through the Sharia. The Sharia consists of a set of laws regarding, among other legal regulations (e.g. marital laws and penal law), business conduct, which are not to be broken, for this is considered sinful and punishable (Khan 2011). 
Table 2 Macro-empirical research

\begin{tabular}{|c|c|c|c|c|}
\hline Author & Religion & Year & Field of publication & CSR dimension \\
\hline $\begin{array}{l}\text { Du, Jian, Du, Feng \& } \\
\text { Zeng }\end{array}$ & Buddhist/Taoist & 2014 & Ethics & Ethical \\
\hline Du, Jian, Lai, Du \& Pei & Buddhist/Taoist & 2015 & Ethics & Legal/Ethical \\
\hline Du, Jian, Zeng \& Du & Buddhist & 2014 & Ethics & Legal/Ethical \\
\hline Cui, Jo \& Velasquez & Christian & 2015 & Ethics & Ethical \\
\hline Cui, Jo \& Velasquez & Christian & 2016 & Ethics & Economic/Ethical \\
\hline Thompson \& Hood & Christian & 1993 & Ethics & Ethical \\
\hline Wishloff & Christian & 2009 & Ethics & Economic/Legal/Ethical \\
\hline Zigan \& Le Grys & Christian & 2018 & Ethics & Ethical \\
\hline Harjoto \& Rossi & CST & 2018 & Management & Ethical \\
\hline $\begin{array}{c}\text { Abdelzaher \& } \\
\text { Abdelzaher }\end{array}$ & Islam & 2017 & Ethics & Economic/Ethical \\
\hline $\begin{array}{l}\text { Alsaadi, Ebrahim \& } \\
\text { Jaafar }\end{array}$ & Islam & 2017 & Finance & Legal/Ethical \\
\hline $\begin{array}{l}\text { Belal, Abdelsalam \& } \\
\text { Nizamee }\end{array}$ & Islam & 2015 & Ethics & Economic/Ethical \\
\hline Elçi \& Alpkan & Islam & 2009 & Ethics & Legal/Ethical \\
\hline Erragragui \& Revelli & Islam & 2016 & Economics & Economic/Legal/Ethical \\
\hline Helfaya, Kotb \& Hanafi & Islam & 2018 & Ethics & Economic/Ethical \\
\hline Kamla \& Rammal & Islam & 2013 & Accounting & Ethical \\
\hline Khan, Lew \& Park & Islam & 2015 & Marketing & Economic/Ethical \\
\hline $\begin{array}{l}\text { Mallin, Farag \& } \\
\text { Ow-Yong }\end{array}$ & Islam & 2014 & Economics & Economic/Legal/Ethical \\
\hline $\begin{array}{l}\text { Platonova, Asutay, } \\
\text { Dixon \& Mohammad }\end{array}$ & Islam & 2018 & Ethics & Economic/Legal/Ethical \\
\hline $\begin{array}{l}\text { Sobhani, Amran \& } \\
\text { Zainuddin }\end{array}$ & Islam & 2012 & Sector Studies & Ethical \\
\hline Williams \& Zinkin & Islam & 2010 & Ethics & Legal/Ethical \\
\hline Attig \& Brockman & Religion (other) & 2017 & Ethics & Ethical \\
\hline Cahan, Chen \& Chen & Religion (other) & 2017 & Ethics & Economic/Ethical \\
\hline $\mathrm{Du}$ & Religion (other) & 2017 & Ethics & Ethical \\
\hline $\begin{array}{l}\text { Du, Du, Zeng, Pei \& } \\
\text { Chang }\end{array}$ & Religion (other) & 2016 & Management & Economic/Legal/Ethical \\
\hline Gazley \& Abner & Religion (other) & 2014 & Sector Studies & Ethical \\
\hline $\mathrm{Li}, \mathrm{Au}, \mathrm{He} \&$ Song & Religion (other) & 2015 & Management & Ethical \\
\hline Weaver \& Agle & Religion (other) & 2002 & Management & Ethical \\
\hline
\end{tabular}

\subsection{Macro-empirical}

The macro-empirical category consists of 28 articles (see Table 2), constituting the largest field in our matrix. In this cell, several articles regarding Christian faith look at the effects of community pressure on firms' CSR. Again, those articles show a 
Table 3 Micro-normative research

\begin{tabular}{lllll}
\hline Author & Religion & Year & Field of publication & CSR dimension \\
\hline Rousseau & CST & 2017 & Ethics & Economic/Ethical \\
Fry \& Cohen & Religion (other) & 2009 & Ethics & Economic/Ethical \\
Sauser, Jr & Religion (other) & 2005 & Ethics & Economic/Legal/Ethical \\
\hline
\end{tabular}

strong affiliation with the ethical dimension of CSR. They find positive effects on employee friendly practices (Cui, Jo and Velasquez 2016), positive effects on female board membership (Harjoto and Rossi 2018) and a negative association between a firm's environmental practices and the degree of religiosity of the region the firm is located (Cui, Jo and Velasquez 2015). Thompson and Hood (1993) find a higher corporate social performance in minority-owned businesses due to the strong connection between Hispanic communities and Christian churches. Macro-empirical research focuses mostly on Islam. Most of these studies look at CSR disclosure practices in the Islamic banking sector. We also find that these articles are spread more evenly across the fields of business research journals, disrupting the pattern of research being mainly conducted in ethics journals. Articles show a strong interest in the legal responsibilities of organizations, as well as ethical responsibilities, probably due to their focus on accounting and disclosure practices. Mallin, Farag, and Ow-Yong (2014) as well as Platonova, Asutay, Dixon, and Mohammad (2018) find a positive correlation between CSR disclosure and financial performance. According to Sobhani, Amran, and Zainuddin (2012), Islamic banks disclose more sustainability information in comparison to conventional banks, but their focus lies on emphasising their religious character, which can lead to lack of disclosure in undesired fields (Kamla and Rammal 2013). Belal, Abdelsalam and Nizamee (2015) find similar evidence: Muslim firms tend to not disclose information in respect of religiously sensitive topics (i.e. income from transactions not in accordance with Sharia law), because they fear that this would damage their "Islamic image". The risk of losing religious and political legitimacy overrides even core Islamic principles, such as accountability and transparency. Alsaadi, Ebrahim and Jaafar (2017) find that Islamic banks with higher CSR performance are less likely to manage their earnings (in contrast to banks listed on a Sharia index). Researchers also found that the tenets of Islam do not contradict the ten principles of the UN Global Compact. In contrast, Williams and Zinkin 2010 argue that the tenets of Islam have the advantage of being more precise about responsibilities regarding business conduct.

Another group of studies deals with the relationship between Buddhism, Taoism, and CSR. By measuring religiosity in relation to the proximity of a firm to religious sites, Du et al. (2014) find a significant positive association between religiosity and corporate environmental responsibility. Du et al. (2014) show a positive relationship between religion and corporate philanthropic giving. Finally, Du et al. (2015) argue that Buddhist and Taoist religions are negatively associated with earnings management.

Studies concerning non-institutionalized forms of religion find a positive relationship of a religious atmosphere on CSR (Du Zeng, Pei and Chang 2016) and a negative relationship between religiosity (measured again by a firm's geographic location) and its overall CSR score (Attig and Brockman 2017). 


\subsection{Micro-normative}

We found very little research done in the micro-normative category. Fry and Cohen's (2009) work on spiritual leadership, Sauser's (2005) appeal concerning how business people should view work as well as Rousseau's (2017) call for the development of executives' moral competences. Rousseau (2017) highlights the importance of CST principles such as moral sensitivity, awareness and motivation for developing executives' moral competences. He argues that these moral competencies lead to a more realistic and coherent perspective on achieving corporate sustainability. Fry and Cohen (2009) argue that strategic leaders should use spiritual leadership to counteract the negative effects of extended work hours. Through spiritual leadership, a work-obsessed individual can still have high psychological well-being, health, and organizational commitment. Sauser (2005) worked on the question of how executives should view work. Focusing on the interrelations between CSR and religion in business conduct, he concludes that business people should view work as a sacred calling in a religious sense.

\subsection{Micro-empirical}

The micro-empirical field consists of 22 articles (see Table 4) and concerns itself with empirical findings at the individual level of analysis. The main focus of this field of research is how managerial religiosity and spirituality influence peoples' CSR attitudes and behavior. On the Christian side, Agle and Van Buren (1999) find a marginal effect of managers' religious attitudes on positive attitudes toward CSR, and Angelidis and Ibrahim (2004) gathered evidence for a significant relationship between the degree of Christian religiosity and attitudes toward economic and ethical components of CSR. Again, Islam features heavily due to the topic of Islamic banking. Although some scholars claim that Muslim managers strongly support CSR, there is no adequate translation of it into practice (Ali Aribi and Arun 2014). Soltani, Syed, Liao, and Iqbal (2015) even find that Muslim managers have little interest in CSR, as CSR is seen as not being congruent with Islamic cultural norms. Islamic cultural norms also make the disclosure of certain information unattractive for Muslim executives in their CSR reports, because it is religiously more beneficial to do good and not talk about it (Hossain, Alam, Islam and Hecimovic 2015). Goby and Nickerson (2016) take a rare approach in looking at Muslim consumers' conceptualization of CSR. They argue that consumers distinguish between CSR and the Muslim principle of Zakat, which is a form of almsgiving. They view CSR mainly as a matter of secular life.

Few articles employ a comparative approach between religions. Brammer, Williams and Zinkin (2007) find that, although religious affiliates have generally similar views on CSR, they disagree on the range of issues CSR should address. Graafland, Kaptein and Mazereeuw-van der Duijn Schouten (2006) detect a correlation between religious belief and business dilemmas: belief in a monotheistic God, transcendental standards of good and evil, and a high intensity of prayer are positively related to the frequency of encounters with business dilemmas. Drawing on Allport and Ross's (1967) intrinsic-extrinsic differentiation in the measurement of religion, Mazereeuw-van der Duijn Schouten, Graafland, and Kaptein (2014) find that intrinsic religiosity positively affects 
Table 4 Micro-empirical research

\begin{tabular}{|c|c|c|c|c|}
\hline Author & Religion & Year & Field of publication & CSR dimension \\
\hline Agle \& Van Buren III & Christian & 1999 & Ethics & Economic/Legal/Ethical \\
\hline Angelidis \& Ibrahim & Christian & 2004 & Ethics & Economic/Legal/Ethical \\
\hline $\begin{array}{l}\text { Mazereeuw_van der } \\
\text { Duijn Schouten, } \\
\text { Graafland \& Kaptein }\end{array}$ & Christian & 2014 & Ethics & Ethical \\
\hline Parker & Christian & 2014 & Accounting & Economic/Legal/Ethical \\
\hline $\begin{array}{l}\text { Swimberghe, Sharma } \\
\text { \& Flurry }\end{array}$ & Christian & 2011 & Ethics & Ethical \\
\hline Ali Aribi \& Arun & Islam & 2014 & Ethics & Economic/Legal/Ethical \\
\hline Goby \& Nickerson & Islam & 2016 & Ethics & Economic/Ethical \\
\hline $\begin{array}{l}\text { Hossain, Alam, Islam } \\
\text { \& Hecimovic }\end{array}$ & Islam & 2015 & Accounting & Legal/Ethical \\
\hline $\begin{array}{l}\text { Soltani, Syed, Liao \& } \\
\text { Iqbal }\end{array}$ & Islam & 2015 & Ethics & Economic/Legal/Ethical \\
\hline $\begin{array}{l}\text { Graafland, Kaptein \& } \\
\text { Mazereeuw_-van der } \\
\text { Duijn Schouten }\end{array}$ & Religiosity & 2007 & Ethics & Economic/Legal/Ethical \\
\hline Hemingway \& Starkey & Religiosity & 2018 & Ethics & Ethical \\
\hline $\begin{array}{l}\text { Hopkins, Shanahan \& } \\
\text { Raymond }\end{array}$ & Religiosity & 2014 & Management & Economic \\
\hline $\begin{array}{l}\text { Ibrahim, Howard \& } \\
\text { Angelidis }\end{array}$ & Religiosity & 2008 & Ethics & Economic/Legal/Ethical \\
\hline Oumlil \& Balloun & Religiosity & 2009 & Ethics & Ethical \\
\hline $\begin{array}{l}\text { Ramasamy, Yeung \& } \\
\text { Au }\end{array}$ & Religiosity & 2010 & Ethics & Economic/Ethical \\
\hline $\begin{array}{l}\text { West, Hillenbrand, } \\
\text { Money, Ghobadian \& } \\
\text { Ireland }\end{array}$ & Religiosity & 2016 & Management & Economic/Ethical \\
\hline Crossman & Spirituality & 2011 & Ethics & Ethical \\
\hline $\begin{array}{l}\text { Giacalone, Paul \& } \\
\text { Jurkiewicz }\end{array}$ & Spirituality & 2005 & Ethics & Economic/Legal/Ethical \\
\hline $\begin{array}{l}\text { Kolodinsky, Madden, } \\
\text { Zisk \& Henkel }\end{array}$ & Spirituality & 2010 & Ethics & Economic/Legal/Ethical \\
\hline $\begin{array}{l}\text { Rahmawati, Jiang, } \\
\text { Law, Wiranatha \& } \\
\text { DeLacy }\end{array}$ & Spirituality & 2018 & Sector Studies & Economic/Ethical \\
\hline $\begin{array}{l}\text { Brammer, Williams \& } \\
\text { Zinkin }\end{array}$ & World Religions & 2007 & Ethics & Economic/Legal/Ethical \\
\hline $\begin{array}{l}\text { Graafland, Kaptein \& } \\
\text { Mazereeuw- van der } \\
\text { Duijn Schouten }\end{array}$ & World Religions & 2006 & Ethics & Economic/Ethical \\
\hline
\end{tabular}

ethical CSR attitudes whereas extrinsic religiosity stimulates philanthropic CSR attitudes.

Aside from the major religions, such as Christianity or Islam, the micro-empirical level of research in the field of CSR and religion is shaped by conceptions of religion 
that cannot be clearly assigned to an institutionalized religion. This may be due to the fact that there is no need to refer to institutionalized religions when measuring different aspects of religion, religiosity and spirituality. Graafland, Kaptein, and Mazereeuwvan der Duijn Schouten (2007), for example, draw on corporate decision makers' conceptions of God, norms and values to examine their orientation towards socially responsible business conduct. They find that executives, who adhere to monotheistic religions, display a stronger orientation towards socially responsible business conduct, as opposed to their pantheistic counterparts. Their findings further indicate that Protestant executives more frequently refer to specific religious ends, such as honouring God, and may act upon this in daily business. However, in a comparative study between managers and students, Ibrahim, Howard, and Angelidis (2008) did not find a significant impact of individual religiousness on CSR orientation.

Beyond research on managerial attitudes, we found only one study on the role of religion in consumer perceptions of CSR. Ramasamy, Yeung, and Au (2010a,b) argue that religious values are a significant determinant of CSR support among consumers.

\section{Discussion and conclusion}

CSR is an important concept that has gained popularity in the last decades. Given the role attributed to religion in the emergence of CSR and its further role in its evolution, it is surprising that relatively little research has been done in this field. To discuss our results we structure this section following the internal logic of Tables 1, 2, 3 and 4, looking at Religion, CSR Dimension, Field of Publication and Normative/Empirical level.

Religion: Generally, the discourse on CSR and religion is heavily focused on the Abrahamic religions, mainly Christianity and Islam. This one-sidedness may stem from a certain anglo- or eurocentrism in research, which creates a bias toward the major Western religions. Some scholars even see the concept of religion in light of its historical genealogy as a concept that is rooted in Christian theology (King 1999). The rationale here is that religion as a category takes the form of a genus divided into different species (Christianity, Islam, Buddhism, etc.), and therefore has the capacity for being sensitive to difference and for drawing useful comparisons. In this vein, different religions are distinguishable by their differing beliefs. But this understanding of religion, far from being universal and trans-historical, in fact, is itself a product of history. Religion was constructed along essentially rationalist lines, and can be seen as a modern invention, which the West, during the last two centuries, has exported to the rest of the world (Hick 1991). Hence, working with the term "religion" can lead to misunderstandings when applied to religions that do not have the same history as Abrahamic religions in Europe (Seth 2009).

The academic focus on Christianity and Islam may also be grounded in the fact that Christianity is still the largest and Islam the fastest growing religious communities worldwide. Due to migration streams, the relevance of Islam as a research topic continues to gain relevance. Moreover, Islam and Christianity, especially Catholicism, build on unified sets of rules and a strong institutional footing, which makes it relatively easy for researchers to approach the field. In turn, the lack of research about other religions may be caused by the lack of a unified set of rules, as is the case with Hinduism 
(Mukherjee 2011), or Protestantism (Küpper 2011b), the latter suffering particularly from a perspectival pluralism (Calkins 2000). While it makes up about 40 percent of world Christianity, there is no single Protestant Church (in the way that there is a single Roman Catholic Church). Protestantism is defined negatively as all Christian individuals or churches that repudiate the office and authority of the Roman Pontiff of the Roman Catholic Church. Some of these are worldwide in scope, such as the Anglican Communion, others are confined to a single country or are solitary church bodies. A Protestant union is further hindered by the fact that each Protestant tradition has staked out its own truth, contrary to the Roman Catholic Church, which applies the principle of extra ecclesiam nulla salus (outside the church is no salvation). The Protestant diversity has an obvious explanation in the absence of a central authoritative entity that would constitute normative authority, as does the Pope in Catholicism (Hillebrand 2014).

That said, the Roman Catholic Church might not be as homogenous as it seems at first glance. It is an interesting field for future research to unveil the impact of different cultural heritages on religion and CSR. Especially colonized countries like America exhibit a large cultural diversity among their Catholics with them stemming from countries like Germany, Irland or France, including people from other cultural backgrounds that were forced to convert to Catholicism like Native Americans and former slaves, or Canadian and Mexican immigrants (Henessey 1983).

Interestingly, given the importance of considering different Christian denominations, in case of Islam, diversity seems not to be a hindrance. Researchers seem to be more acutely aware of Christian denominations where Islam is treated as a collective singular in the reviewed articles, without distinguishing Muslim traditions, such as the Shia, Sunni or Alevite traditions. However, Islamic denominations differ for example in the question of succession (i.e., who was to inherit the leading authority after the death of the prophet Muhammed) and in daily practices, such as the modality of Wudu (ritual washing before prayer), Salat (the prayer itself), and Sawn (the practice of fasting) (Ameli and Molaei 2012). The more economically relevant Qur' anic principles in turn, such are the prohibition of usury, gambling and speculation, vary only in degree.

While capitalistic values can be traced back to the rise of Protestantism (Weber (2001/1904), religions such as Hinduism or Confucianism give little importance to the material world and consequently would not focus much on economic conduct, which would explain the lack of research on them (Giddens 2012). Buddhism, on the other hand, may challenge the Western business paradigm of profit-maximization, which emerged in the wake of capitalistic values, the cultivation of desire and the instrumental use of the world's resources too far to be viable for the Western context (Zsolnai 2011). Although the number of atheists and agnostics is rising and nowadays makes up between 500 Mio. and 750 Mio. non-believers, making irreligion one of the largest 'faiths' (Zuckerman 2007), there is basically no research done on the absence of religion. This poses an interesting gap. Looking at the absence of religion in relation to attitudes towards CSR and comparing them with the insights of research encompassing religion could yield interesting results and give the influence of religion new meaning in this regard.

CSR Dimension: Taking a closer look at the assigned CSR dimensions, based on Schwartz and Carroll's (2003) three-domain approach, we observed that the various dimensions are distributed non-uniformly. The ethical has the highest score, with 29 
entries, followed by Econ/Eth 22, Econ/Leg/Eth 20, Leg/Eth 5, Econ/Leg 2, Economic 1 and Legal 0 (as assigned in Tables 1, 2, 3, 4).

The prevalence of the ethical domain, including the overlapping domains containing ethical aspects, may be largely explained by the research topic at hands: religion. These domains include responsiveness to domestic and global ethical imperatives and in the case of religion to a deontological standard. This standard embodies those activities, which reflect a consideration of one's duty or obligation (De George 1999). Deontological principles of religiosity compliment the ethical dimension, which otherwise focuses on conventional moral rights and justice. The utilization of deontological principles captures a broader range of potential ethical justifications (Herman 1997; De George 1999). Thus, it seems unsurprising that, with the inclusion of deontological standards, there is barely a dimension without the influence of the ethical domain, when dealing with the intersection of CSR and religion.

Again, Islam takes a special place. Over half of the articles regarding Islam are connected to dimensions overlapping with the legal aspects of CSR. This stems from articles dealing with Islamic banking, which heavily concern themselves with questions of compliance to legal and religious standards. The second largest intersection is the Econ/Leg/Eth dimension. This category conforms to Carroll's (1987) moral management, according to which management desires profitability, but only within the confines of obeying the law and being sensitive to ethical standards. From a normative standpoint, this is the category where firms should seek to operate whenever possible (Schwartz and Carroll 2003).

Field of publication: As our review shows, literature on the relation between religion and CSR is relatively new and has mainly arisen in the last decade, with the majority of articles being published in ethics journals. Little work is published outside the field of ethics. What stands out is that the few articles that are published outside are mainly articles about Islam in accounting and finance journals. This is probably due to the research focus on Islamic banking, accounting and disclosure practices, although high ranking accounting journals, like the Accounting Review, the Journal of Accounting and Economics, the Journal of Accounting Research, the Contemporary Accounting Research or the Review of Accounting Studies, do not concern themselves with the intersection of CSR and religion. We have only one match in a high ranked accounting journal, Accounting, Organizations and Society, which interestingly looks at industrial pioneers and the influence of their Christian background on their CSR efforts. Another peculiarity is the hegemony of the categories of "Religiosity" and "Religion (other)" in management journals. Management research seems to rely on rather diffuse concepts of religion to investigate the empirical impact of spirituality on managers' and workers' attitudes and behaviors.

Concerning the two dimensions of our conceptual framework, most research on the relation between religion and CSR is done at the macro level following an empirical approach. Herein, Islam has a certain predominance, due to the number of research papers that deal with Islamic banking. Accounting, financing and disclosure practices are at the center of research in Islamic banking; therefore, it is not surprising that much empirical research on this deals with the legal and ethical aspects of CSR.

Normative/empirical level: Normative research at the macro level is represented in a similar quantity. Herein, CST holds a dominant position, probably due to its easy and 
accessible application to business. Often research in this area fails to offer a transition into business practice and may seem moralizing. Detached from empirical research, normative reasoning misses the chance to generate a practical impact (Schreck, van Aaken and Donaldson 2013). Research, for example, about the CST form of transparency in business (Vaccaro and Sison 2011a,b) or about the effects of a political perspective of CSR from the standpoint of normative Islam (Murphy and Smolarski 2018) would benefit enormously from empirical data. Thus, for religious prescriptions to gain mass appeal, empirical backing is needed.

The normative research on the relation between religion and CSR shows a lack of micro-level research. Given the nature of normative reasoning, research at the microlevel is not an easy task. However, it could yield interesting and new approaches to the field of CSR and religion. Concepts like spiritual leadership (Fry 2003) are well established and may contribute to the literature, when paired with CSR. Religion is often seen as an internal and individual force and should as such be easily applicable to the micro context.

Empirical research in the field of religion and CSR is heterogeneous in the way religion is measured. Two articles seldom choose the same methodology. Nonetheless, the literature focuses on similar research questions, as is the case, for example, for articles on Muslim banking. The different empirical approaches to religion may yield an extensive understanding of the subject, but also risk the danger of fragmentation. Micro-level research about CSR and religion deals mostly with the CSR attitudes of religious individuals. Samples mostly consist of executives and business students to represent managers' attitudes towards CSR and their religion's influence on it. There has been very little research on the CSR attitudes of religious consumers or other stakeholders. Exploring religious consumers' valuation of CSR initiatives could yield interesting results and help firms to decide on specific CSR endeavours. Moreover, this field of research would benefit from the introduction of empirical methods that unveil real-life behavior (like experimental economics) instead of solely focusing managerial attitudes. Religiouslyinfluenced moral attitudes may be largely lip service. Whether religiously-motivated attitudes prevail in standard business situations is still an open question.

Acknowledgements Open access funding provided by Paris Lodron University of Salzburg.

Open Access This article is licensed under a Creative Commons Attribution 4.0 International License, which permits use, sharing, adaptation, distribution and reproduction in any medium or format, as long as you give appropriate credit to the original author(s) and the source, provide a link to the Creative Commons licence, and indicate if changes were made. The images or other third party material in this article are included in the article's Creative Commons licence, unless indicated otherwise in a credit line to the material. If material is not included in the article's Creative Commons licence and your intended use is not permitted by statutory regulation or exceeds the permitted use, you will need to obtain permission directly from the copyright holder. To view a copy of this licence, visit http://creativecommons.org/licenses/by/4.0/.

\section{Appendix A}

\section{Appendix 1}

See Tables 5, 6, 7 and 8 


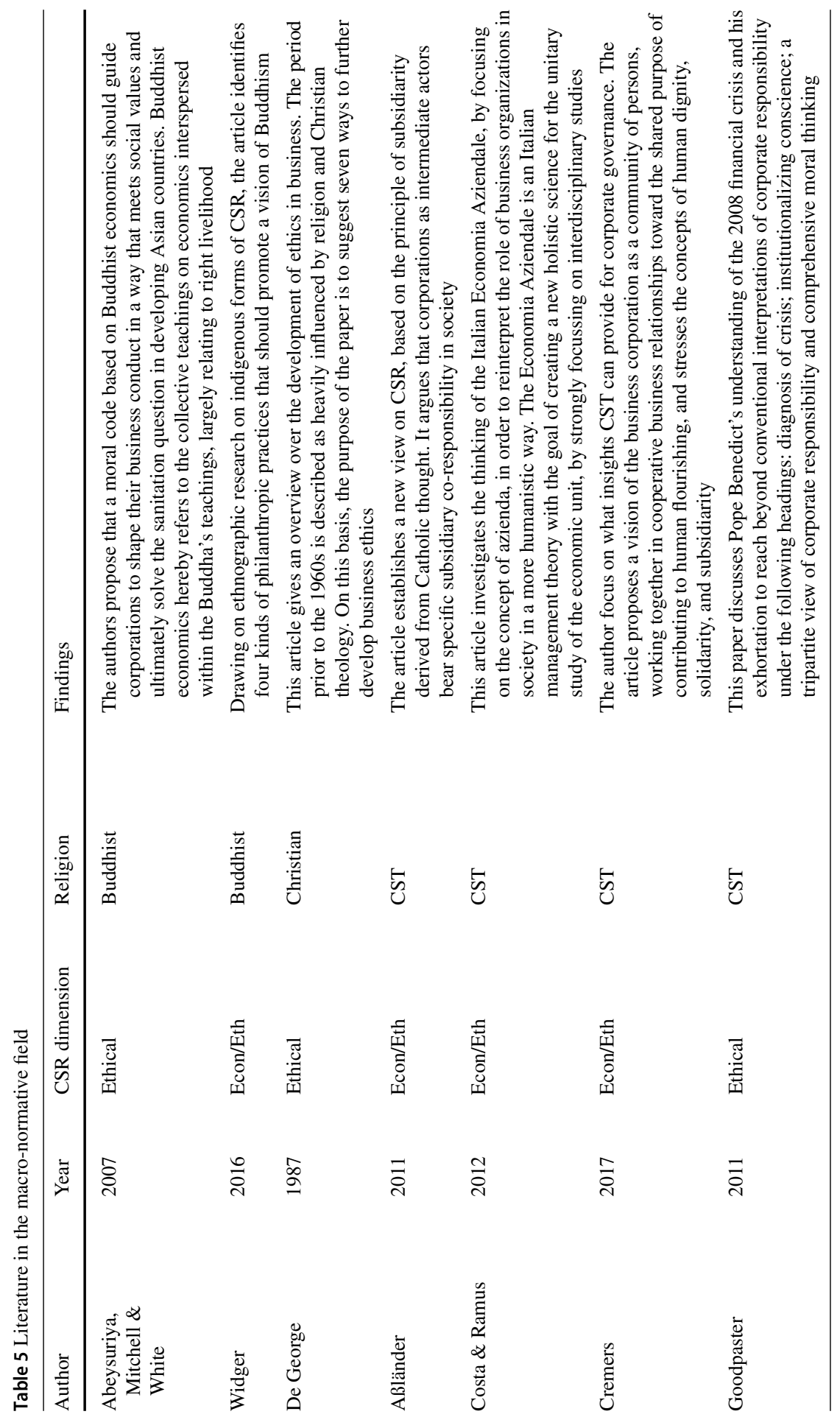




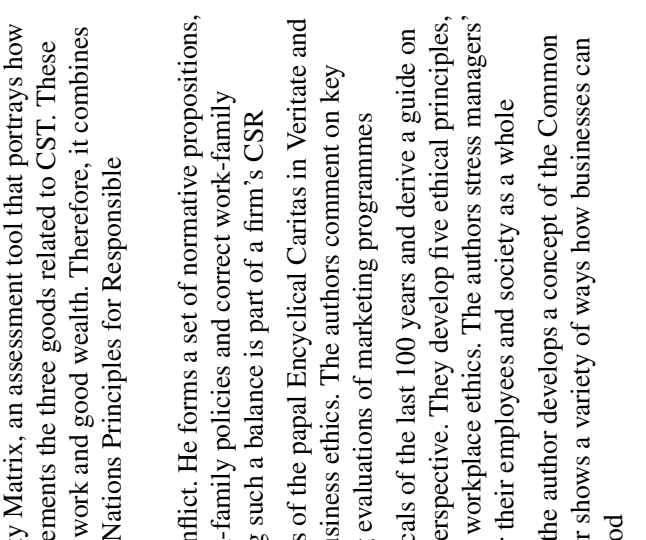

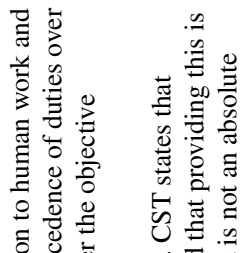

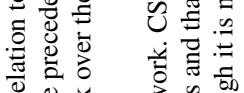

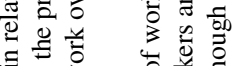

育范范

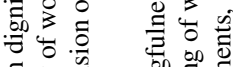

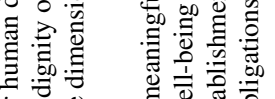

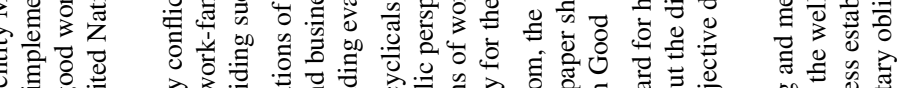

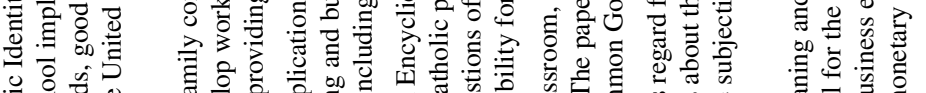

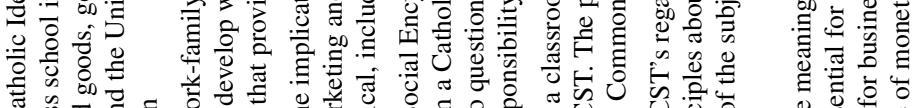

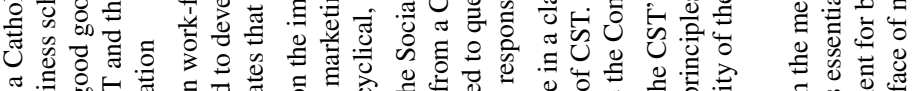

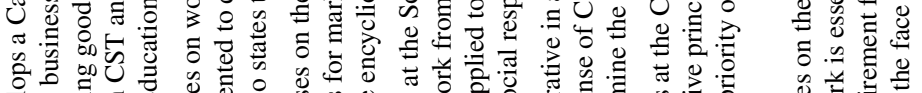
ôे

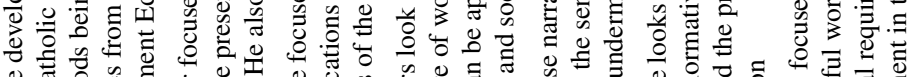

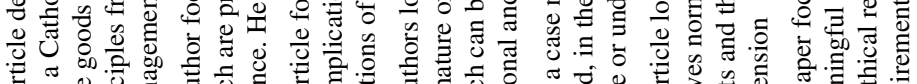

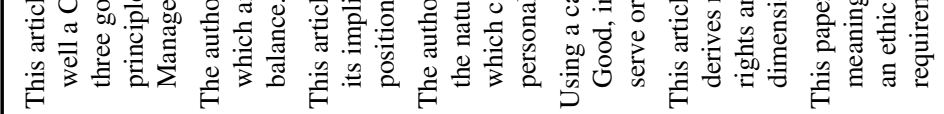
$F$ F $F$ F

$\begin{array}{lllll}5 & 5 & 5 & 5 & 5\end{array}$

$\overline{8}$

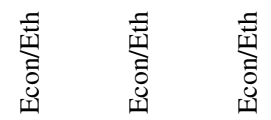

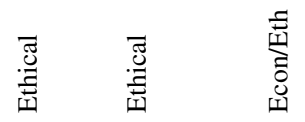

$\stackrel{2}{2} \quad \stackrel{2}{2}$

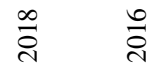

$\stackrel{n}{\stackrel{2}{2}}$

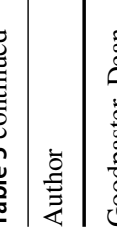

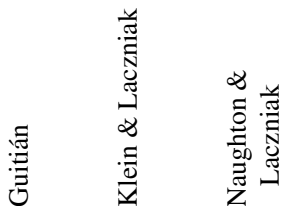

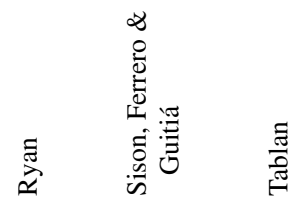




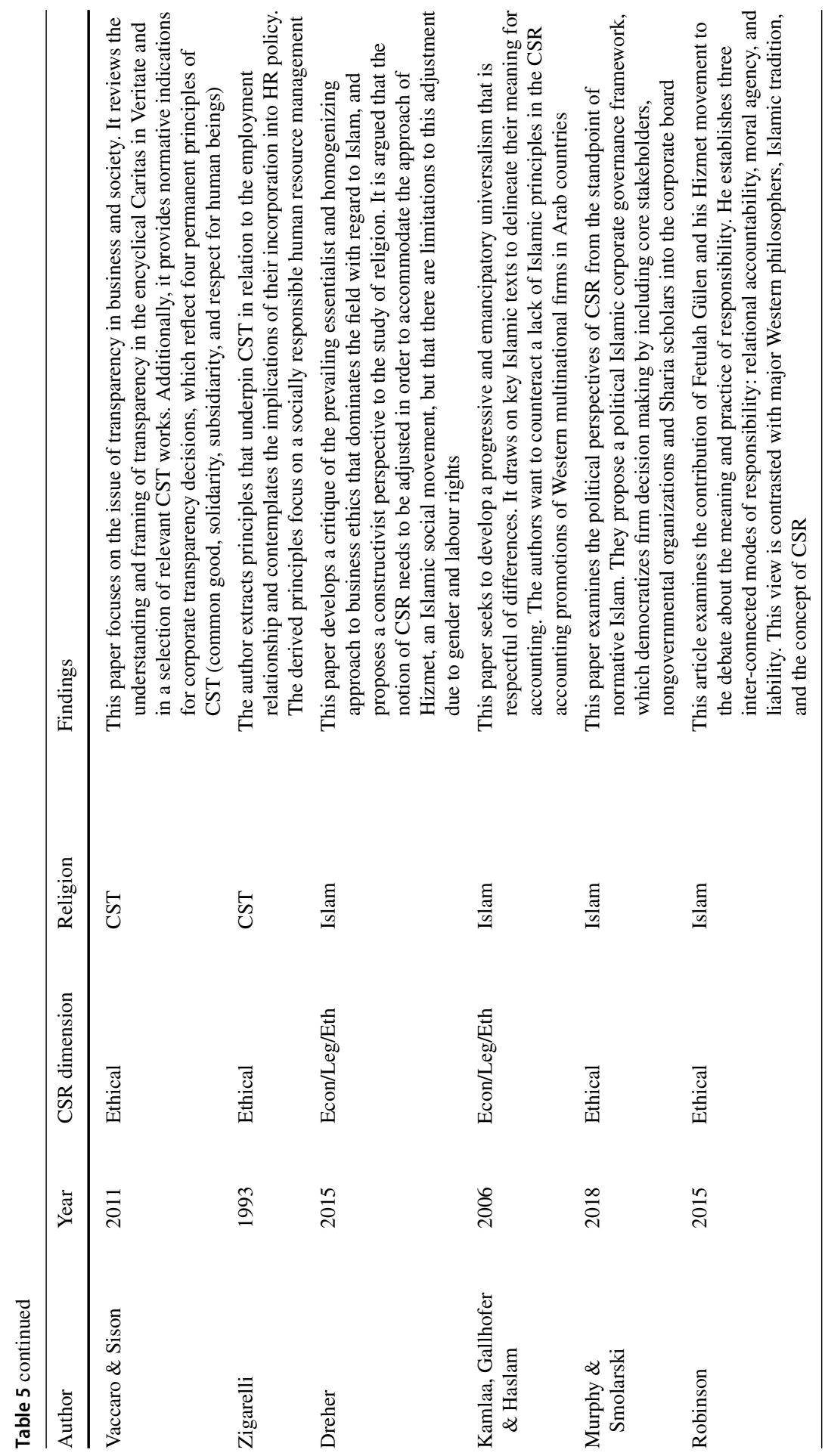




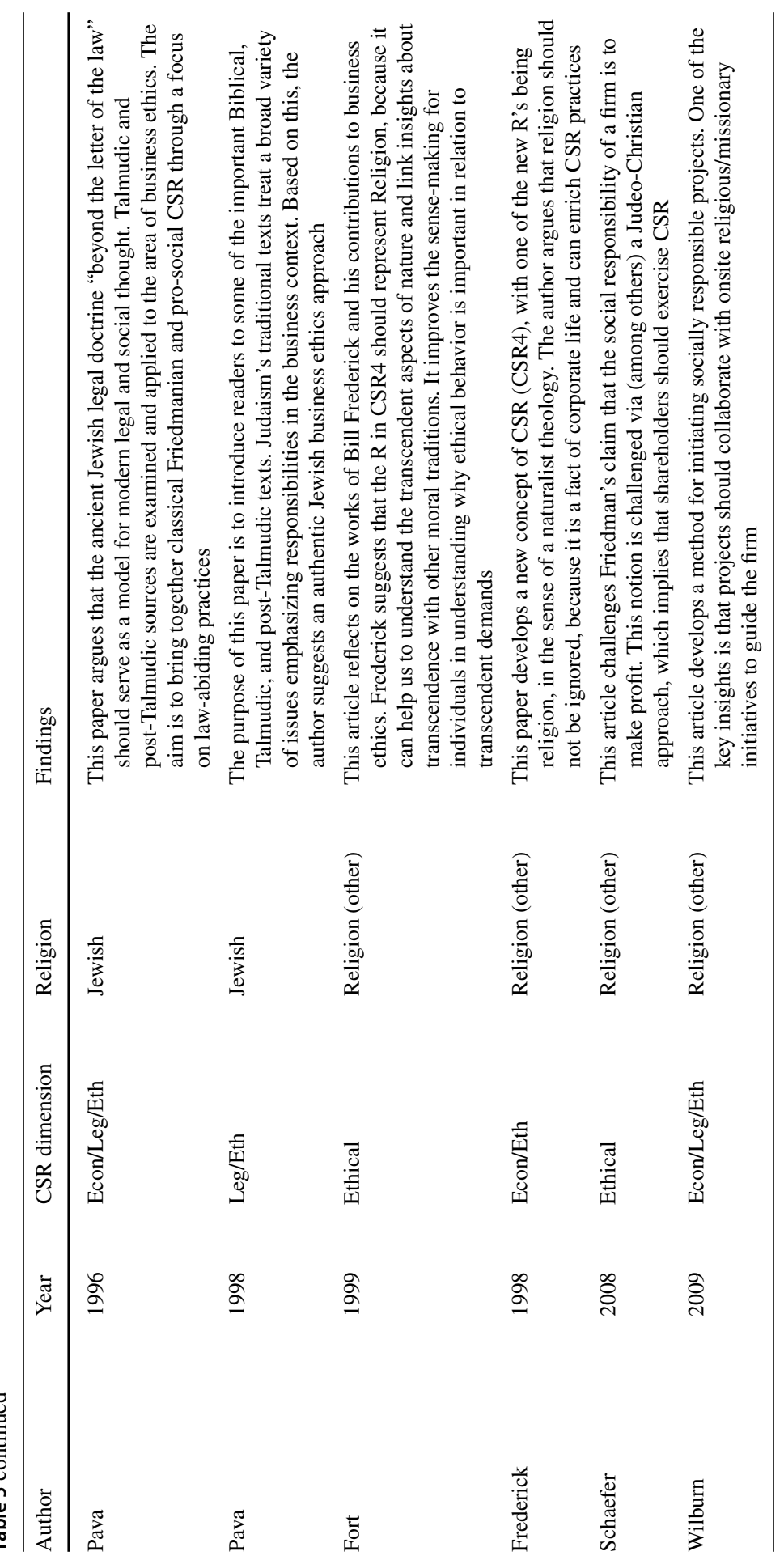


Table 6 Literature in the macro-empirical field

\begin{tabular}{|c|c|c|c|}
\hline Author & Year & CSR dimension & Religion \\
\hline Du, Jian, Du, Feng \& Zeng & 2014 & Ethical & Buddhist/Taoist \\
\hline Du, Jian, Lai, Du \& Pei & 2015 & Leg/Eth & Buddhist/Taoist \\
\hline Du, Jian, Zeng \& Du & 2014 & Leg/Eth & Buddhist \\
\hline Cui, Jo \& Velasquez & 2015 & Ethical & Christian \\
\hline Cui, Jo \& Velasquez & 2016 & Econ/Eth & Christian \\
\hline Thompson \& Hood & 1993 & Ethical & Christian \\
\hline Wishloff & 2009 & Econ/Leg/Eth & Christian \\
\hline Zigan \& Le Grys & 2018 & Ethical & Christian \\
\hline Harjoto \& Rossi & 2018 & Ethical & CST \\
\hline Abdelzaher \& Abdelzaher & 2017 & Econ/Eth & Islam \\
\hline Alsaadi, Ebrahim \& Jaafar & 2017 & Leg/Eth & Islam \\
\hline Belal, Abdelsalam \& Nizamee & 2015 & Econ/Eth & Islam \\
\hline Elçi \& Alpkan & 2009 & Leg/Eth & Islam \\
\hline Erragragui \& Revelli & 2016 & Econ/Leg/Eth & Islam \\
\hline Helfaya, Kotb \& Hanafi & 2018 & Econ/Eth & Islam \\
\hline Kamla \& Rammal & 2013 & Ethical & Islam \\
\hline Khan, Lew \& Park & 2015 & Econ/Eth & Islam \\
\hline Mallin, Farag \& Ow-Yong & 2014 & Econ/Leg/Eth & Islam \\
\hline Platonova, Asutay, Dixon \& Mohammad & 2018 & Econ/Leg/Eth & Islam \\
\hline Sobhani, Amran \& Zainuddin & 2012 & Ethical & Islam \\
\hline Williams \& Zinkin & 2010 & Leg/Eth & Islam \\
\hline Attig \& Brockman & 2017 & Ethical & Religion (other) \\
\hline Cahan, Chen \& Chen & 2017 & Econ/Eth & Religion (other) \\
\hline $\mathrm{Du}$ & 2017 & Ethical & Religion (other) \\
\hline Du, Du, Zeng, Pei \& Chang & 2016 & Econ/Leg/Eth & Religion (other) \\
\hline Gazley \& Abner & 2014 & Ethical & Religion (other) \\
\hline Li, Au, He \& Song & 2015 & Ethical & Religion (other) \\
\hline Weaver \& Agle & 2002 & Ethical & Religion (other) \\
\hline
\end{tabular}




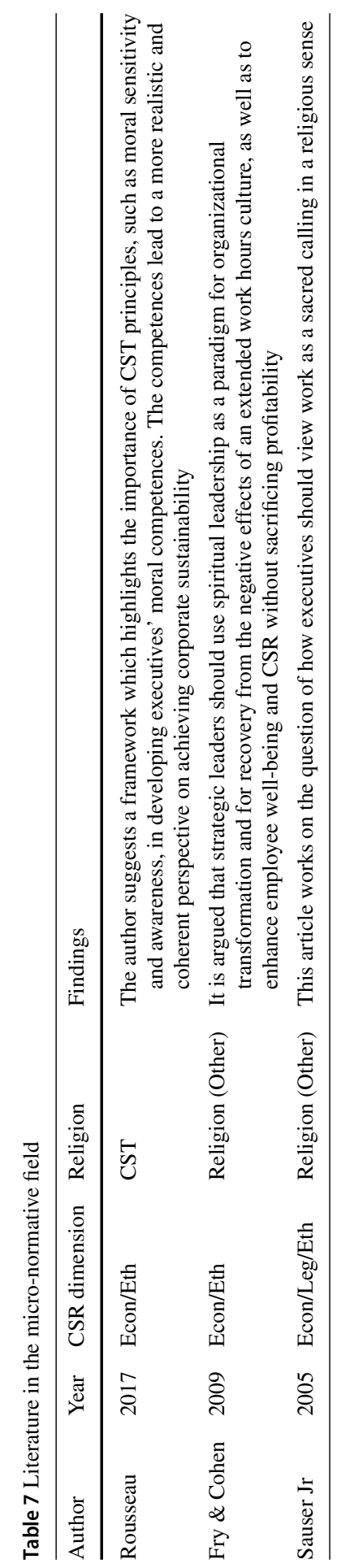




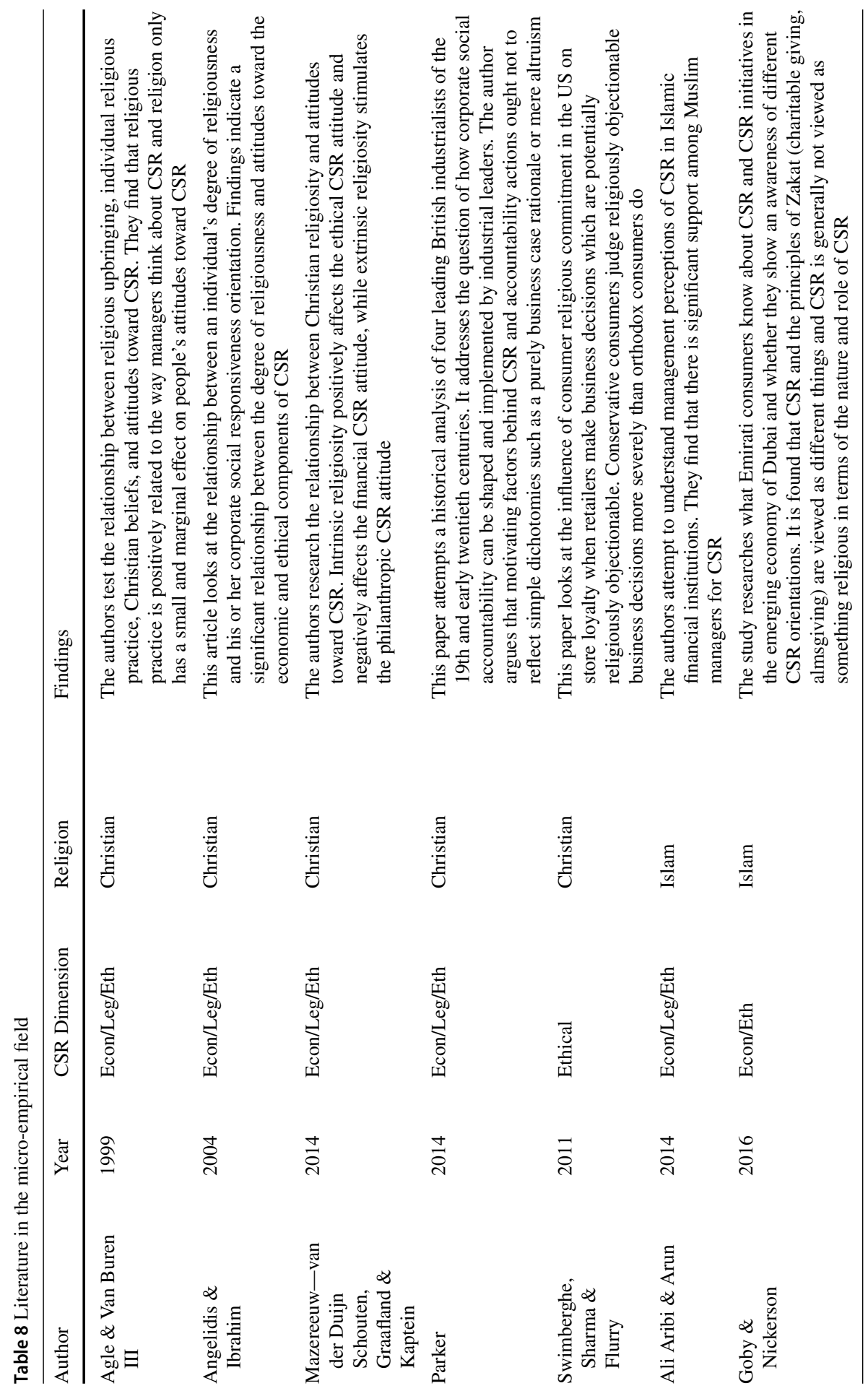




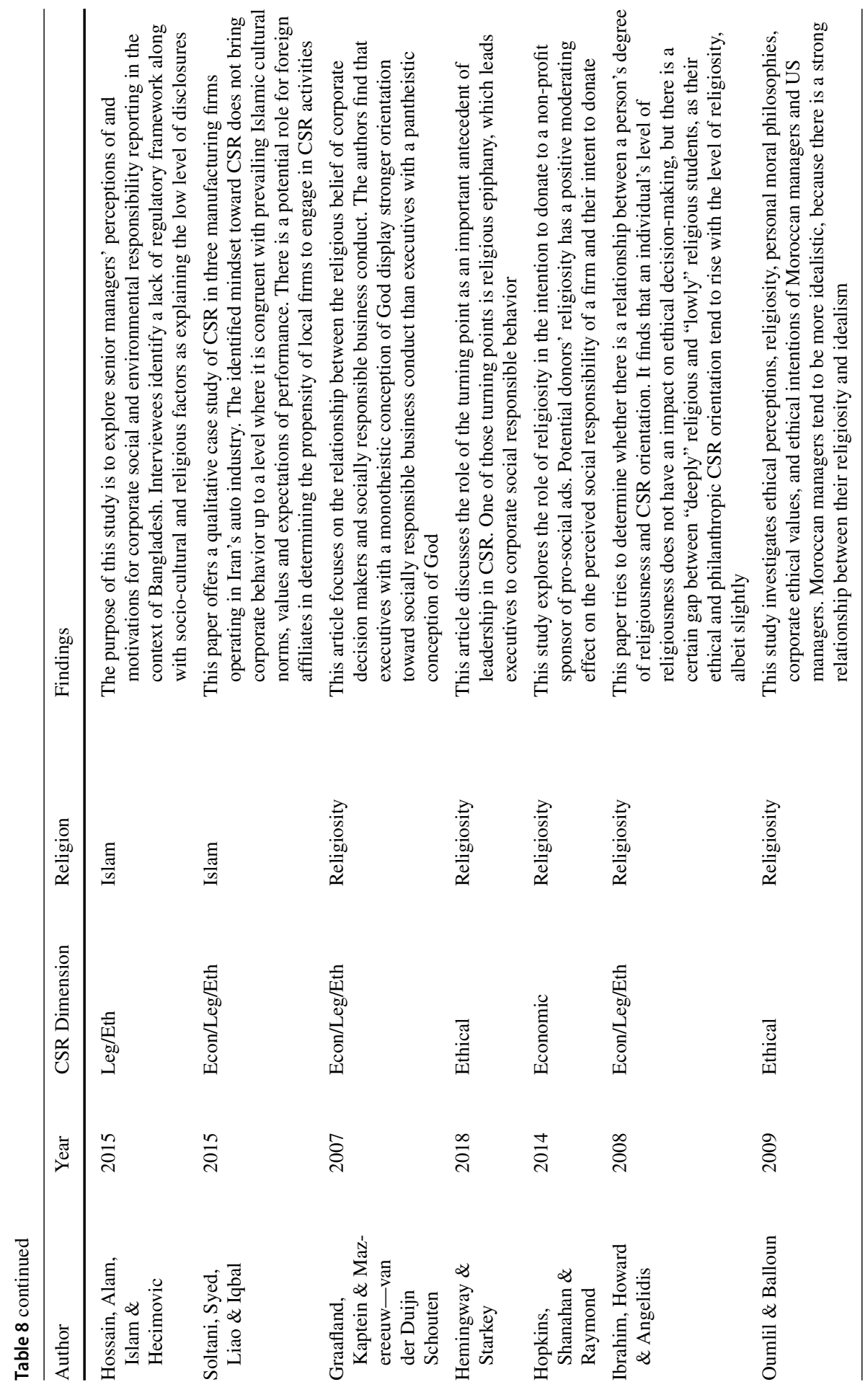




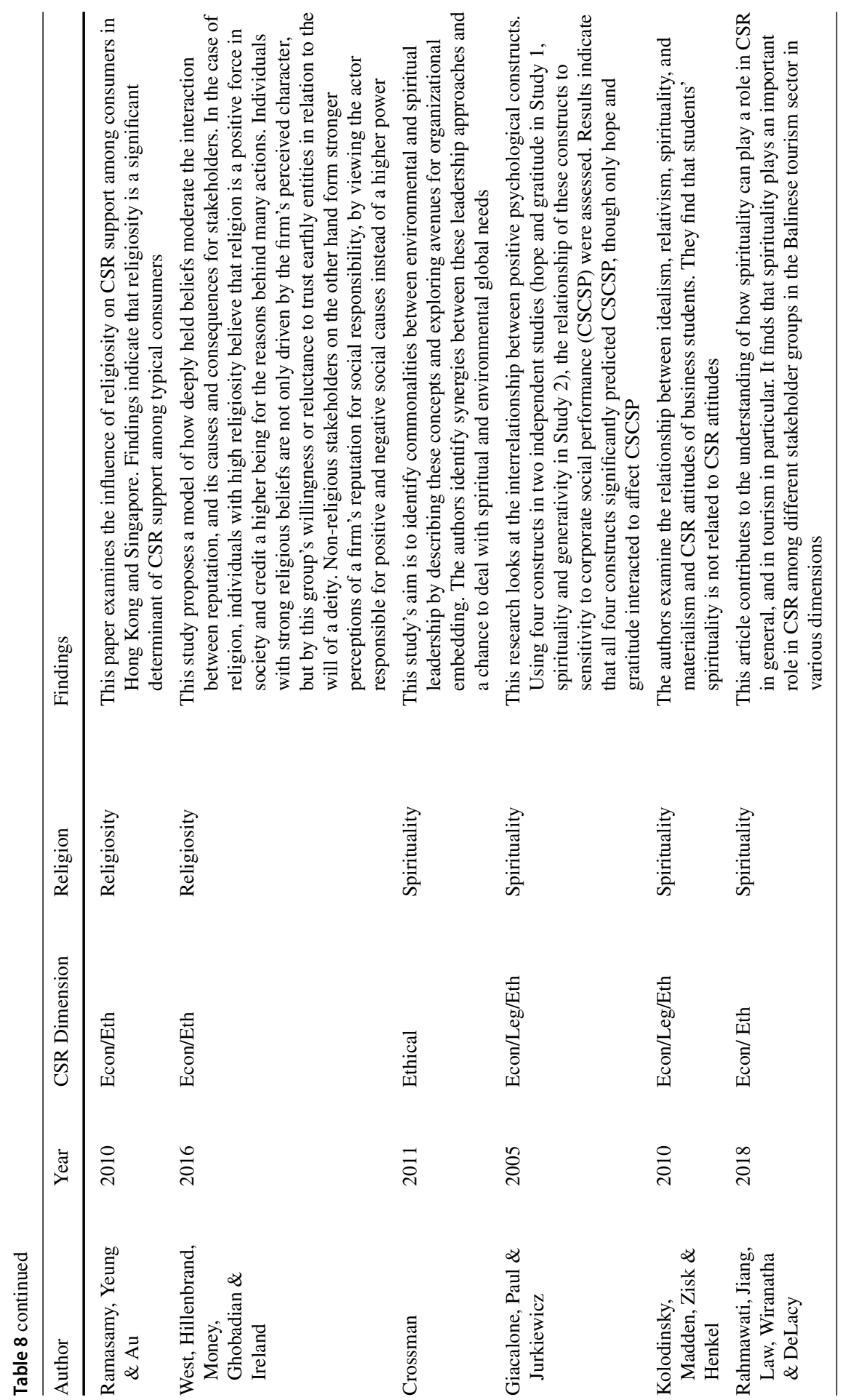




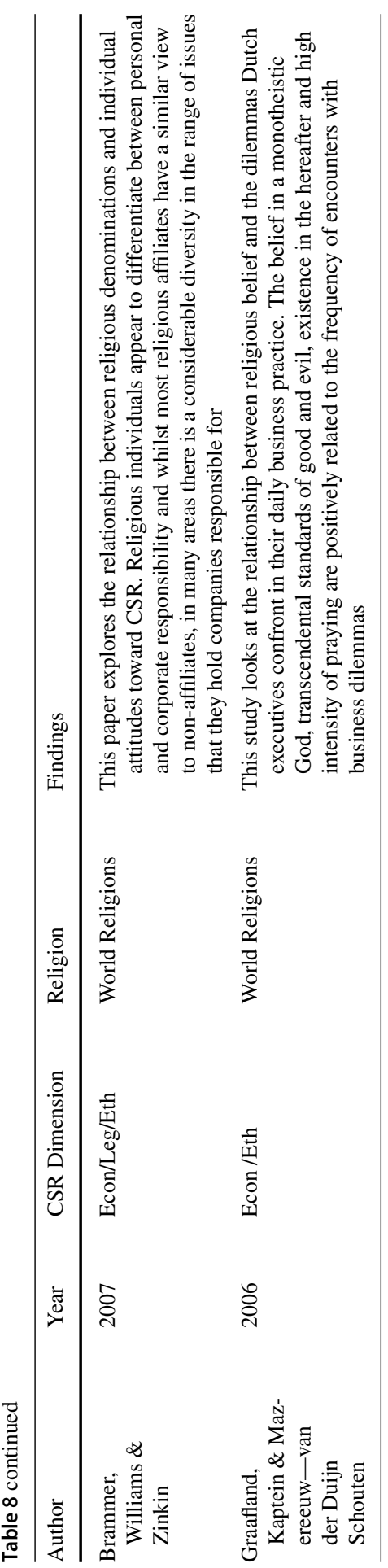




\section{References}

Aßländer M (2011) Corporate social responsibility as subsidiary co-responsibility: a macroeconomic perspective. J Bus Ethics 99(1):115-128

Abdelzaher DM, Abdelzaher A (2017) Beyond environmental regulations: Exploring the potential of "ecoIslam" in boosting environmental ethics within SMEs in Arab markets. J Bus Ethics 145:357-371

Abeysuriya K, Mitchell C, White S (2007) Can corporate social responsibility resolve the sanitation question in developing Asian countries? Ecol Econ 62(1):174-183

Agle BR, Van Buren HJ (1999) God and mammon: The modern relationship. Bus Ethics Q 9(4):563-582

Aguinis H (2011) Organizational responsibility: Doing good and doing well. In: Zedeck S (ed) APA handbook of industrial and organizational psychology, (3). American Psychological Association, Washington, pp 855-879

Aguinis H, Glavas A (2012) What we know and don't know about corporate social responsibility: a review and research agenda. J Manag 38(4):932-968

Ali Aribi Z, Arun T (2014) Corporate social responsibility and Islamic financial institutions (IFIs): Management perceptions from IFIs in Bahrain. J Bus Ethics 129(4):785-794

Allport GW, Ross M (1967) Personal religious orientation and prejudice. J Pers Soc Psychol 5(4):432-443

Alsaadi A, Ebrahim M, Jaafar A (2017) Corporate social responsibility, shariah-compliance, and earnings quality. J Financ Serv Res 51(2):169-194

Ameli SR, Molaei H (2012) Religious affiliation and intercultural sensitivity: Interculturality between Shia \& Sunni Muslims in Iran. Int J Intercult Relat 36(1):31-40

Angelidis J, Ibrahim N (2004) An exploratory study of the impact of degree of religiousness upon an individual's corporate social responsiveness orientation. J Bus Ethics 51(2):119-128

Attig N, Brockman P (2017) The local roots of corporate social responsibility. J Bus Ethics 142(3):479-496

Belal AR, Abdelsalam O, Nizamee SS (2015) Ethical reporting in Islamic bank in Bangladesh limited (1983-2010). J Bus Ethics 129:769-784

Blum U, Dudley L (2001) Religion and economic growth: was Weber right? J Evolut Econ 11(2):207-230

Bowen HR (1953) Social responsibilities of the businessman. Harper \& Row, New York

Brammer S, Williams G, Zinkin J (2007) Religion and attitudes to corporate social responsibility in a large cross-country sample. J Bus Ethics 71(3):229-243

Brown DL, Vetterlein A, Roemer-Mahler S (2010) Theorizing transnational corporations as social actors: an analysis of corporate motivations. Bus Politics 12(1):1-37

Cahan S, Chen C, Chen L (2017) Social norms and CSR performance. J Bus Ethics 145(3):493-508

Calkins M (2000) Recovering religion's prophetic voice for business ethics. J Bus Ethics 23:339-352

Carroll AB (1987) In search of the moral manager. Bus Horiz 30(2):7-15

Carroll AB (1991) The pyramid of corporate social responsibility: toward the moral management of organizational stakeholders. Bus Horiz 34(4):39-48

Carroll AB (1999) Corporate social responsibility: Evolution of a definitional construct. Bus Soc 38(3):268-295

Cremers M (2017) What corporate governance can learn from Catholic social teaching. J Bus Ethics 145(4):711-724

Crossman J (2011) Environmental and spiritual leadership: Tracing the synergies from an organizational perspective. J Bus Ethics 103(4):553-565

Costa E, Ramus T (2012) The Italian economia aziendale and catholic social teaching: how to apply the common good principle at the managerial level. J Bus Ethics 106(1):103-116

Cui J, Jo H, Velasquez M (2015) The influence of christian religiosity on managerial decisions concerning the environment. J Bus Ethics 132(1):203-231

Cui J, Jo H, Velasquez M (2016) Community religion, employees, and the social license to operate. J Bus Ethics 136(4):775-807

De George RT (1987) The Status of business ethics: Past and future. J Bus Ethics 6(3):201-211

De George RT (1999) Business Ethics, 5th edn. Prentice Hall, Upper Saddle River

Dreher S (2015) Islamic capitalism? The turkish Hizmet business community network in a global economy. J Bus Ethics 129(4):823-832

Du X (2017) Religious belief, corporate philanthropy, and political involvement of entrepreneurs in Chinese family firms. J Bus Ethics 142(2):385-406

Du X, Du Y, Zeng Q, Pei H, Chang Y (2016) Religious atmosphere, law enforcement, and corporate social responsibility: Evidence from China. Asia Pacific J Manag 33(1):229-265 
Du X, Jian W, Du Y, Fend W, Zeng Q (2014) Religion, the nature of ultimate owner, and corporate philanthropic giving: Evidence from China. J Bus Ethics 123(2):235-256

Du X, Jian W, Lai S, Du Y, Pei H (2015) Does religion mitigate earnings management? Evidence from China. J Bus Ethics 131:699-749

Du X, Jian W, Lai S, Du Y, Pei H (2015a) Does religion mitigate earnings management? Evidence from China. J Bus Ethics 131(3):699-749

Du X, Jian W, Quan Z, Du Y (2014) Corporate environmental responsibility in polluting industries: Does religion matter? J Bus Ethics 124(3):485-507

Elliot S (2011) Transdisciplinary perspectives on environmental sustainability: a resource base and framework for IT-enabled business transformation. MIS Quarterly 35(1):197-236

Elçi M, Alpkan L (2009) The impact of perceived organizational ethical climate on work satisfaction. J Bus Ethics 84(3):297-311

Enderle G, Murphy PE (2009) Ethics and corporate social responsibility for marketing in the global marketplace. In: Kotabee M, Helsen K (eds) The Sage handbook of international marketing. Sage, Thousand Oaks, pp 504-531

Erragragui E, Revelli C (2016) Is it costly to be both shariah compliant and socially responsible? Rev Financ Econ 31:64-74

Fort TL (1999) Business and naturlism: A peek at transcendence. Bus Soc 38(2):226-236

Frambach H, Eissrich D (2016) Der dritte Weg der Päpste: Die Wirtschaftsideen des Vatikans. UVK Verlagsgesellschaft mbH, Konstanz

Fry LW (2003) Toward a theory of spiritual leadership. Leadersh Quarterly 14(6):693-727

Fry L, Cohen M (2009) Spiritual leadership as a paradigm for organizational transformation and recovery from extended work hours cultures. J Bus Ethics 84:265-278

Frederick WC (1998) Moving to CSR: What to pack for the trip. Bus Soc 37(1):40-59

Frederick WC (1994) From CSR1 to CSR2: The maturing of business-and-society thought. Bus Soc 33:150-164

Garriga E, Melé D (2004) Corporate social responsibility theory: Mapping the territory. J Bus Ethics 53(1/2):51-71

Gazley B, Abner G (2014) Evaluating a product donation program: Challenges for charitable capacity. Nonprofit Manag Leadersh 24(3):337-355

Giacalone RA, Paul K, Jurkiewicz CL (2005) A preliminary investigation into the role of positive psychology in consumer sensitivity to corporate social performance. J Bus Ethics 25(4):295-305

Giddens A (2012) Sociology (revised and updated with Philip W. Sutton). Polity Press, Cambridge

Goby V, Nickerson C (2016) Conceptualization of CSR among Muslim consumers in Dubai: Evolving from philanthropy to ethical and economic orientations. J Bus Ethics 136(1):167-179

Goodpaster KE (2011) Goods that are truly good and services that truly serve: Reflections on 'caritas in veritate'. J Bus Ethics 100:9-16

Graafland J, Kaptein M (2006) Business dilemmas and religious belief: An explorative study among Dutch executives. J Bus Ethics 66(1):53-70

Graafland J, Kaptein M (2007) Conceptions of God, normative convictions, and socially responsible business conduct - An explorative study among executives. Bus Soc 46(3):331-369

Guitián G (1988) Conciliating work and family: A catholic social teaching perspective. J Bus Ethics 88(3):513-524

Goodpaster KE, Dean Maines T, Naughton M, Shapiro B (2018) Using UNPRME to teach, research, and enact business ethics: Insights from the Catholic identity matrix for business schools. J Bus Ethics 147(4):761-777

Harjoto MA, Rossi F (2018) Religiosity, female directors, and corporate social responsibility for Italian listed companies. J Bus Res 95:338-346

Hennesey J (1983) American Catholics: A History of the Roman Catholic Community in the United States. Oxford University Press, Oxford

Helfaya A, Kotb A, Hanafi R (2018) Qur'anic ethics for environmental responsibility: Implications for business practice. J Bus Ethics 150(4):1105-1128

Hemingway CA, Starkey K (2018) A falling of the veils: Turning points and momentous turning points in leadership and the creation of CSR. J Bus Ethics 151(4):875-890

Herman SW (1997) Enlarging the conversation. Bus Ethics Q 7(2):5-20

Hick J (1991) The Meaning and End of Religion. Fortress, Minneapolis

Hillebrand HJ (2014) The Encyclopaedia of Protestantism, vol 1-4. Routledge, London, New York 
Hopkins CD, Shanahan KJ, Raymond MA (2014) The moderating role of religiosity on nonprofit advertising. J Bus Res 67(2):23-31

Hossain MM, Alam M, Islam MA, Hecimovic A (2015) Do stakeholders or social obligations drive corporate social and environmental responsibility reporting? Managerial views from a developing country. Qual Res Account Manag 12(3):287-314

Ibrahim N, Howard D, Angelidis J (2008) The relationship between religiousness and corporate social responsibility orientation: Are there differences between business managers and students? J Bus Ethics 78(1/2):165-174

Jurkiewicz CL, Giacalone RA (2004) A values framework for measuring the impact of workplace spirituality on organizational performance. J Bus Ethics 49(2):129-142

Kamlaa R, Gallhofer S, Haslam J (2006) Islam, nature and accounting: Islamic principles and the notion of accounting for the environment. Account Forum 30(3):245-265

Kamla R, Rammal HG (2013) Social reporting by Islamic banks: does social justice matter? Accout Audit Account J 26(6):911-945

Khan F (2011) Islamic economics. In: Bouckart L, Zsolnai L (eds) Handbook of spirituality and business. Palgrave MacMillan, New York, pp 138-146

Khan Z, Lew YK, Park BI (2015) Institutional legitimacy and norms-based CSR marketing practices. Int Market Rev 32(5):463-491

King R (1999) Orientalism and religion: postcolonial theory, India and "The Mystic East". Routledge, London

Klein T, Laczniak G (2013) Implications of caritas in veritate for marketing and business ethics. J Bus Ethics 112(4):641-651

Kolodinsky R, Madden T, Zisk D, Henkel E (2010) Attitudes about corporate social responsibility: Business student predictors. J Bus Ethics 91(2):167-181

Küpper HU (1974) Grundlagen einer Theorie der betrieblichen Mitbestimmung: Wissenschaftslogische und realtheoretische Perspektiven einer betriebswirtschaftlichen Analyse der betrieblichen Mitbestimmung. Duncker-Humblot, Berlin

Küpper HU (2011) Religion, Unternehmensethik und Betriebswirtschaftslehre. In: Liedhegener A, TungerZanetti A, Wirz S (eds) Religion - Wirtschaft - Politik: Forschungszugänge zu einem aktuellen transdisziplinären Feld. Pano Verlag, Zürich, pp 327-350

Küpper HU (2011a) Unternehmensethik: Hintergründe, Konzepte, Anwendungsbereiche. SchäfferPoeschel, Stuttgart

Küpper HU, van Aaken D, Schreck P (2011) Notwendigkeit, Ziele und Inhalte einer Ethik-Ausbildung in der Betriebswirtschaftslehre. Zeitschrift für Betriebswirtschaft 81(1):39-62

Li W, Au KY, He A, Song L (2015) Why do family-controlled firms donate to charity? The role of intrafamily succession intention, social status, and religiosity. Manag Organ Rev 11(4):621-644

Lockett A, Moon J, Visser W (2006) Corporate social responsibility in management research: focus, nature, salience and sources of influence. J Manage Stud 43(1):115-136

Maignan I, Ferrell OC (2004) Corporate social responsibility and marketing: an integrative framework. J Acad Mark Sci 32(1):3-19

Mazeereuw-van der Duijn Schouten C, Graafland J, Kaptein M (2014) Religiosity, CSR attitudes, and CSR behavior: an empirical study of executives' religiosity and CSR. J Bus Ethics 123(3):437-459

Moher D, Liberati A, Tetzlaff J, Altman DG, the PRISMA Group (2009) Preferred reporting items for systematic reviews and meta-analyses: The prisma statement. Ann Intern Med 151(4):264-269

Morse JM, Hupcey JE, Penrod J, Spiers JA, Pooler C, Mitcham C (2002) Symposium conclusion - Issues of validity: Behavioral concepts, their derivation and interpretation. Int J Qual Methods 1(4):68-73

Mukherjee S (2011) Indian Management Philosophy. In: Bouckart L, Zsolnai L (eds) Handbook of Spirituality and Business. Palgrave MacMillan, New York, pp 80-87

Murphy MJ, Smolarski JM (2018) Religion and CSR: An Islamic "political” model of corporate governance. Bus Soc

Mallin C, Farag H, Ow-Yong K (2014) Corporate social responsibility and financial performance in Islamic banks. J Econ Behav Organ 103:21-38

Naughton M, Laczniak GR (1993) A theological context of work from the catholic social encyclical tradition. J Bus Ethics 12(12):981-994

Oumlil AB, Balloun JL (2009) Ethical decision-making differences between American and Maroccan managers. J Bus Ethics 84:457-478 
Pava ML (1996) The Talmudic concept of "beyond the letter of the law": Relevance to business social responsibilities. J Bus Ethics 15(9):941-950

Pava ML (1998) Developing a religiously grounded business ethics: A Jewish perspective. Bus Ethics Q 8(1):65-83

Parboteeah KP, Paik Y, Cullen JB (2009) Religious group and work values: a focus on Buddhism, Christianity, Hinduism, and Islam. Int J Cross Cultural Manag 9(1):51-67

Parker LD (2014) Corporate social accountability through action: Contemporary insights from British industrial pioneers. Account Organ Soc 39(8):632-659

Platonova E, Asutay M, Dixon R, Mohammad S (2018) The impact of corporate social responsibility disclosure on financial performance: Evidence from the GCC Islamic banking sector. J Bus Ethics 151(2):451-471

Ramasamy B, Yeung M, Au A (2010) Consumer support for corporate social responsibility (CSR): The role of religion and values. J Bus Ethics 91:61-72

Rahmawati PI, Jiang M, Law A, Wiranatha AS, DeLacy T (2018) Spirituality and corporate social responsibility: an empirical narrative from the Balinese tourism industry. J Sustain Tour online https://www. tandfonline.com/loi/rsus20

Ryan MR (2018) Teaching the common good in business ethics: A case study approach. J Bus Ethics 147(4):693-704

Robinson S (2015) Islam, responsibility and business in the thought of Fethullah Gülen. J Bus Ethics 128(2):369-381

Rousseau H (2017) Corporate sustainability: Toward a theoretical integration of catholic social teaching and the natural-resource-based view of the firm. J Bus Ethics 145(4):725-737

Sauser WI Jr (2005) Ethics in business: Answering the call. J Bus Ethics 58(4):345-357

Schaefer B (2008) Shareholders and social responsibility. J Bus Ethics 81(2):297-312

Schreck P, van Aaken D, Donaldson T (2013) Positive economics and the normativistic fallacy: bridging the two sides of CSR. Bus Ethics Q 23(2):297-329

Schwartz MS, Carroll AB (2003) Corporate Social Responsibility: A Three-Domain Approach. Bus Ethics Q 13(4):503-530

Scott RW (1995) Institutions and Organizations. Sage, Thousand Oaks

Secchi D (2007) Utilitarian, managerial and relational theories of corporate social responsibility. Int J Manag Rev 9(4):347-373

Seth S (2009) Historical sociology and postcolonial theory: Two strategies for challenging eurocentrism. Int Political Sociol 3(3):334-338

Singer M (1966) Religion and social change in India: the Max Weber Thesis, Phase Three. Econ Dev Cult Change 14(4):497-505

Sison AJ, Ferrero I, Guitián G (2016) Human dignity and the dignity of work: Insights from Catholic social teaching. Bus Ethics Q 26(4):503-528

Sobhani FA, Amran A, Zainuddin Y (2012) Sustainability disclosure in annual reports and websites: a study of the banking industry in Bangladesh. J Clean Product 23(1):75-85

Solani E, Syed J, Liao Y, Iqbal A (2015) Managerial mindsets toward corporate social responsibility: The case of auto industry in Iran. J Bus Ethics 129(4):795-810

Swanson SL (1999) Toward an integrative theory of business and society: A research strategy for corporate social performance. Acad Manag Rev 24(3):506-521

Swimberghe K, Sharma D, Flurry L (2011) Does a consumer's religion really matter in the buyer-seller dyad? An empirical study examining the relationship between consumer religious commitment, Christian conservatism and the ethical judgment of a seller's controversial business decision. J Bus Ethics 102(4):581-598

Tablan F (2015) Catholic social teachings: Toward a meaningful work. J Bus Ethics 128(2):291-303

Thompson JK, Hood JN (1993) The practice of corporate social performance in minority- versus nonminority-owned small businesses. J Bus Ethics 12(3):197-206

Treviño L, Weaver GR (1994) Business ethics: One field or two? Bus Ethics Q 4(2):111-125

Tyrell H (1992) "Das Religiöse” in Max Webers Religionssoziologie. Saeculum 43(2/3):172-230

Vaccaro A, Sison A (2011) Transparency in business: The perspective of Catholic social teaching and the 'caritas in veritate'. J Bus Ethics 100(1):17-27

Weaver GR, Agle BR (2002) Religiosity and ethical behaviour in organizations: a symbolic interactionist perspective. Acad Manag Rev 27(1):77-97

Weber M (1963) The Sociology of Religion. Beacon Press, London 
Weber M (2001) The Protestant Ethic and the Spirit of Capitalism. Routledge, New York

West B, Hillenbrand C, Money K, Ghobadian A, Ireland D (2016) Exploring the impact of social axioms on firm reputation: A stakeholder perspective. Br J Manag 27(2):249-270

Widger T (2016) Philanthronationalism: Junctures at the business-charity nexus in post-war Sri Lanka. Dev Change 47(1):29-50

Wilburn K (2009) A model for partnering with not-for-profits to develop socially responsible businesses in a global environment. J Bus Ethics 85:111-120

Williams G, Zinkin J (2010) Islam and CSR: A study of the compatibility between the zenets of Islam and the UN global compact. J Bus Ethics 91(4):519-533

Wishloff J (2009) The land of realism and the shipwreck of idea-ism: Thomas Aquinas and Milton Friedman on the social responsibilities of business. J Bus Ethics 85(2):137-155

Zigan K, Le Grys A (2018) Towards an understanding of social responsibility within the church of England. J Bus Ethics 149(3):535-560

Zigarelli MA (1993) Catholic social teaching and the employment relationship: A model for managing human resources in accordance with Vatican doctrine. J Bus Ethics 12(1):75-82

Zuckerman P (2007) Atheism: Contemporary numbers and patterns. In: Martin M (ed) The Cambridge Companion to Atheism. Cambridge University Press, New York, pp 47-65

Zsolnai L (2011) Buddhist Economics. In: Bouckart L, Zsolnai L (eds) Handbook of Spirituality and Business. Palgrave MacMillan, New York, pp 88-94

Publisher's Note Springer Nature remains neutral with regard to jurisdictional claims in published maps and institutional affiliations. 